\title{
PENINGKATAN KAPASITAS BADAN USAHA MILIK DESA (BUMDes) MAPAN DESA PANJALIN KIDUL
}

\author{
Dadang Sudirno, Masduki, L Suparto, Dede Salim Nahdi, Toto Sumianto \\ Universitas Majalengka \\ dsudirno@unma.ac.id
}

\begin{abstract}
Village-Owned Enterprises, or BUMDes, are basically pillars of economic activity in the village that function as social and commercial institutions. As a village effort, the establishment of BUMDes is really to maximize the potential of the village community in terms of economic potential, natural resources, or human resources. In its development, the presence of BUMDes in regions, including in Majalengka Regency, especially in Panjalin Kidul Village, experienced ups and downs due to many factors including low managerial capacity, lack of empowerment of local communities, and BUMDes infrastructure not yet optimal. Bumdesa Mapan Panjalin Kidul Village has the potential to develop because it has human resources (management), financial support and assets that can be utilized. However, due to the lack of management knowledge in running BUMDesa, BUMDesa has not been able to function optimally. This community service is carried out using the method of socialization and training. From this activity the results were obtained that almost all participants understood and had the ability to manage BUMDes.
\end{abstract}

Keywords: enhancement, BUMDes.

\begin{abstract}
Abstrak
Badan Usaha Milik Desa atau disebut BUMDes pada dasarnya merupakan pilar kegiatan ekonomi di desa yang berfungsi sebagai lembaga sosial juga komersial. Sebagai sebuah usaha desa, pembentukan BUMDes adalah benar-benar untuk memaksimalisasi potensi masyarakat desa baik itu potensi ekonomi, sumber daya alam, ataupun sumber daya manusianya. Dalam perkembangannya keberadaan BUMDes di daerah termasuk di Kabupaten Majalengka, khususnya di Desa Panjalin Kidul, mengalami pasang surut disebabkan banyak faktor diantaranya, rendahnya kapasitas manajerial, kurangnya Pemberdayaan masyarakat lokal, dan Infrastruktur BUMDes belum optimal. Bumdesa Mapan Desa Panjalin Kidul memiliki potensi untuk berkembang karena memilki sumberdaya manusia (pengurus), dukungan keuangan serta aset yang dapat dimamfaatkan. Namun karena masih minimnya pengetahuan pengurus dalam menjalankan BUMDesa, menyebabkan BUMDesa belum dapat berfungsi dengan optimal. Kegiatan pengabdian ini dilaksanakan dengan metode sosialisasi dan pelatihan. Dari kegiatan ini diperoleh hasil bahwa hampir seluruh peserta memahami dan memiliki kemampuan dalam melakukan pengelolaan BUMDes.
\end{abstract}

Kata Kunci: peningkatan, BUMDes

\section{Pendahuluan}

Badan Usaha Milik Desa atau disebut BUMDes pada dasarnya merupakan pilar kegiatan ekonomi di desa yang berfungsi sebagai lembaga sosial juga komersial. BUMDes adalah merupakan badan usaha milik desa yang didirikan atas dasar kebutuhan dan potensi desa sebagai upaya peningkatan kesejahteraan masyarakat (Depdiknas, 2007). BUMDes sebagai lembaga sosial memiliki peran dan keberpihakan kepada masyarakat melalui upaya penyediaan layanan sosial. Hal ini sesuai dengan tujuan pendirian Bumdes secara umum yaitu: (1) Meningkatkan Perekonomian Desa, (2) Meningkatkan Pendapatan 
asli Desa, (3) Meningkatkan Pengelolaan potensi desa sesuai dengan kebutuhan masyarakat, dan (4) Menjadi tulang punggung pertumbuhan dan pemerataan ekonomi desa (Ridlwan, 2014). Saat ini proses pembangunan desa sebagai upaya memajukan perekonomian bangsa telah memiliki dasar hukum yang kuat, yaitu Undang Undang Desa. Dalam implementasinya, Undang Undang Desa memiliki beberapa tujuan utama, yaitu: 1) pengakuan dan status hukum pada sistem pemerintahan setingkat desa yang beragam di Indonesia; 2) mendorong tradisi dan kebudayaan masyarakat; 3) mendorong partisipasi warga dalam pemerintahan desanya; 4) meningkatkan pelayanan untuk semua orang lewat lebih sanggupnya pemerintahan desa; 5) mendorong pembangunan oleh oleh warganya sendiri.

Dikeluarkan regulasi yang mendukung pelaksanaan Undang-Undang Desa seperti Peraturan Pemerintah Nomor. 60 Tahun 2014 tentang Dana Desa, mendorong desa harus mampu mengatur dan berperan aktif dalam membangun desa dengan alokasi dana yang diperoleh masing-masing desa. Hal ini berarti bahwa dana desa diadakan dengan dua cita-cita yaitu pemerintah desa lebih bisa sanggup melayani kebutuhan warga, sekaligus warganya lebih aktif berinisiatif. Salah satu wadah untuk memajukan ekonomi desa adalah Badan Usaha Milik Desa atau BUMDes. Pendirian BUMDes melekat pada visi-misi pemerintahan desa setempat.

Tujuan awal pembentukan BUMDes pada dasarnya dimaksudkan untuk mendorong atau menampung seluruh kegiatan yang menstimulan peningkatan pendapatan masyarakat, baik yang berkembang menurut adat istiadat dan budaya setempat, maupun kegiatan perekonomian yang diserahkan untuk dikelola oleh masyarakat melalui program atau proyek Pemerintah Pusat dan Pemerintah Daerah (Sofyan, 2015). Sebagai sebuah usaha desa, pembentukan BUMDes adalah benar-benar untuk memaksimalisasi potensi masyarakat desa baik itu potensi ekonomi, sumber daya alam, ataupun sumber daya manusianya. Secara spesifik, pendirian Bumdes adalah untuk menyerap tenaga kerja desa meningkatkan kreatifitas dan peluang usaha ekonomi produktif mereka yang berpenghasilan rendah. Sasaran pemberdayaan ekonomi masyarakat desa melalui BUMDes ini adalah untuk melayani masyarakat desa dalam mengembangkan usaha produktif. Tujuan lainnya adalah untuk menyediakan media beragam usaha dalam menunjang perekonomian masyarakat desa sesuai dengan potensi desa dan kebutuhan masyarakat.

Dalam perkembangannya keberadaan BUMDes didaerah termasuk di Kabupaten Majalengka mengalami pasang surut disebabkan banyak faktor diantaranya :

1. Kapasitas manajerial, antara lain berkaitan dengan administrasi maupun inventarisasi serta keuangan. Pencatatan keuangan umumnya belum menerapkan standar akuntansi. Pencatatan yang dilakukan masih sederhana. Selain itu, permasalahan transparansi dalam pelaporan rutin BUMDes. Padahal ini sangat penting terkait dengan besarnya nilai aset, omset, dan akuntabilitas kelembagaan BUMDes.

2. Pemberdayaan masyarakat lokal. Keberadaan BUMDes seharusnya menjadi lapangan kerja dan akses ekonomi untuk masyarakat didesa. Namun sebagian masyarakat menilai jika BUMDes belum memberdayakan masyarakat sekitar. Karyawan BUMDes umumnya berasal dari luar desa yang merupakan orang dekat aparat desa, dan tidak melalui proses rekrutmen yang transparan. Selain itu, aspek pemberdayaan 
masyarakat desa belum sepenuhnya terwujud karena aset Bumdes masih didominasi pelaku usaha dari luar desa.

3. Infrastruktur BUMDes belum optimal. Umumnya BUMDes belum banyak memanfaatkan sarana serta aset yang ada. BUMDes juga membutuhkan dukungan infrastruktur berupa perbaikan jalan, penerangan, penataan kios, serta pengadaan dan perawatan aset yang dimiliki oleh BUMDes.

Ketiga permasalahan diatas, juga berlaku di BUMDes Mapan Desa Panjalin Kidul Kecamatan Sumberjaya. Meski BUMDes Mapan telah pendiriannya melalui Surat Keputusan Kepala Desa Panjalin Kidul No. 12/Pankid/VII/2017. Namun sampai saat in BUMDes Mapan belum beroperasi dan menjalankan fungsinya dengan optimal. Berdasarkan hasil observasi awal yang dilaksanakan pada tanggal 17-19 Juni 2019, dengan melakukan wawacara terbuka terhadap pengurus BUMDes Mapan, aparatur desa (Kasi Pemerintahan dan Kasi Pembangunan Ekonomi) serta beberapa tokoh masyarakat, diperoleh informasi tentang kondisi BUMDesa Mapan. Bumdes Mapan Desa Panjalin Kidul memiliki potensi untuk berkembang karena memilki sumberdaya manusia (pengurus), dukungan keuangan serta aset yang dapat dimamfaatkan. Namun karena masih minimnya pengetahuan pengurus dalam menjalankan BUMDesa, menyebabkan BUMDesa belum dapat berfungsi dengan optimal. Oleh karena itu, kami mencoba untuk melakukan kegiatan Pengabdian Masyarakat dalam bentuk pelatihan dan penyuluhan kepada BUMDesa Mapan Desa Panjalin Kidul Kecamatan Sumberjaya, dengan harapan pengurus memiliki pengetahuan dan kapasitas dalam menjalankan BUMDesa, sehingga BUMDesa dapat berfungsi sebagaimana yang diharapkan oleh masyarakat Desa Panjalin Kidul.

Kegiatan Pengabdian Kepada Masyarakat ini ini bertujuan untuk :

1. Memberikan pengetahuan kepada pengurus BUMDesa Mapan tentang organisasi dan tata kelola BUMDesa;

2. Memberikan pengetahuan kepada pengurus BUMDesa Mapan tentang perencanaan dan pengembangan bisnis BUMDesa;

3. Memberikan pengetahuan kepada pengurus BUMDesa Mapan tentang akuntansi keuangan BUMDesa;

4. Memberikan pelatihan kepada pengurus BUMDesa Mapan tentang administrasi dan pengelolaan keuangan BUMDesa.

Pengetahuan dan kapasitas pengurus BUMDesa, merupakan faktor kunci dalam menjalankan BUMDesa. Semakin tinggi pengetahuan dan kapasitas pengurus, BUMDesa akan dapat beroperasi dengan optimal sesuai dengan fungsinya sebagai pilar perekonomian desa. Dengan dimilikinya pengetahuan tata kelola, manajerial, perencanaan bisnis dan administrasi serta pengelolaan keuangan oleh pengurus, maka BUMDesa akan mampu memamfaatkan setiap potensi SDA dan lingkungan sebagai bagian dari bisnis BUMDesa. Sehingga BUMDesa dapat menjadi semakin handal dan terpercaya sebagai unit usaha desa yang mampu berkontribusi mengurangi kemiskinan diperdesaan.

\section{Metode}

Berdasarkan solusi permasalahan yang dijelaskan di atas, maka metode pelaksanaan kegiatan pengabdian kepada masyarakat yang akan dilakukan dapat disajikan pada tabel di bawah ini : 
Tabel 1

Metode Pelaksanaan dan Sasaran Kegiatan PKM

\begin{tabular}{|c|c|c|}
\hline Solusi & Metode Pelaksanaan & Sasaran \\
\hline $\begin{array}{l}\text { Penyuluhan } \\
\text { Pengembangan } \\
\text { Kapasitas Pengurus } \\
\text { tentang } \\
\text { Pengorganisasia, } \\
\text { Tata Kelola, } \\
\text { Perencanaan dan } \\
\text { Pengembangan } \\
\text { Bisnis BUMDes. }\end{array}$ & $\begin{array}{ll}\text { 1. } & \text { Ceramah } \\
\text { 2. Fokus Grop Diskusi }\end{array}$ & $\begin{array}{l}\text { 1. Pengurus BUMDes } \\
\text { 2. Aparatur desa } \\
\text { 3. Tokoh masyarakat } \\
\text { 4. Organisasi masyarakat } \\
\text { (BPD, LPM, LSM, dan } \\
\text { lainnya) }\end{array}$ \\
\hline $\begin{array}{l}\text { Pelatihan } \\
\text { Pengelolaan, } \\
\text { Administrasi dan } \\
\text { Akuntansi } \\
\text { Keuangan BUMDes. }\end{array}$ & $\begin{array}{l}\text { 1. Ceramah } \\
\text { 2. Latihan Kasus }\end{array}$ & $\begin{array}{l}\text { 1. Pengurus BUMDes } \\
\text { 2. Aparatur desa } \\
\text { 3. Tokoh masyarakat } \\
\text { 4. Organisasi masyarakat } \\
\text { (BPD, LPM, LSM, dan } \\
\text { lainnya) }\end{array}$ \\
\hline $\begin{array}{l}\text { Penyuluhan } \\
\text { Manajemen } \\
\text { Pengelolaan Aset } \\
\text { Desa. }\end{array}$ & $\begin{array}{l}\text { 1. Ceramah } \\
\text { 2. Fokus Grop Diskusi }\end{array}$ & $\begin{array}{l}\text { 1. Pengurus BUMDes } \\
\text { 2. Aparatur desa } \\
\text { 3. Tokoh masyarakat } \\
\text { 4. Organisasi masyarakat } \\
\text { (BPD, LPM, LSM, dan } \\
\text { lainnya) }\end{array}$ \\
\hline
\end{tabular}

\section{Hasil dan Pembahasan}

Berdasarkan pelaksanaan kegiatan pengabdian kepada masyarakat yang telah dilaksankan tersebut, maka dapat dijabarkan hasil yang diperoleh sebagai berikut :

Tabel 4.2

Hasil Pengabdian Kepada Masyarakat

\begin{tabular}{|c|c|c|}
\hline Kegiatan & $\begin{array}{c}\text { Target } \\
\text { (Indikator Kegiatan) }\end{array}$ & Hasil Kegiatan \\
\hline $\begin{array}{l}\text { Penyuluhan } \\
\text { Pengelolaan dan } \\
\text { Pengembangan } \\
\text { BUMDesa }\end{array}$ & $\begin{array}{l}\text { 1. } 80 \% \text { Pengurus } \\
\text { memahami } \\
\text { pengelolaan } \\
\text { BUMDes } \\
\text { 2. Tersusunnya draft } \\
\text { AD/ART BUMDes }\end{array}$ & $\begin{array}{l}\text { 1. 90\% pengurus memahami tentang keberadaan } \\
\text { BUMDes, dan bagaimana pengelolaannya } \\
\text { berdasarkan peraturan yang ada. Hal ini dapat } \\
\text { dilihat dari kemampuan para pengurus untuk } \\
\text { menyusun visi misi dan tujuan BUMDes } \\
\text { 2. Draft AD/ART BUMDes belum dapat tersusun, } \\
\text { oleh karenanya akan dilakukan pendampingan } \\
\text { lebih lanjut. }\end{array}$ \\
\hline $\begin{array}{l}\text { Penyuluhan } \\
\text { Manajemen Aset } \\
\text { Desa }\end{array}$ & $\begin{array}{l}80 \% \quad \text { Pengurus } \\
\text { BUMDes memahami } \\
\text { pengelolaan aset desa }\end{array}$ & $\begin{array}{l}\text { 1. 90\% pengurus memahami tentang aset desa } \\
\text { 2. Inventarisasi aset desa akan dilakukan oleh } \\
\text { BUMDes sebagai bagian pemetaan potensi } \\
\text { desa. }\end{array}$ \\
\hline
\end{tabular}




$\begin{array}{llr}\text { Penyuluhan } & 80 \% & \text { Pengurus } \\ \text { Pengembangan } & \text { memahami } & \text { potensi } \\ \text { Usaha BUMDesa } & \text { usaha BUMDes }\end{array}$

Penyuluhan

Perencanaan dan

Kelayakan Usaha BUMDesa

1. $80 \%$ Pengurus dapat memahami rencana dan kelayakan bisnis

Pelatihan
Penyusunan
Rencana Bisnis
BUMDesa

Penyuluhan Manajemen Keuangan BUMDesa

Pelatihan Administrasi dan Pelaporan Keuangan BUMDesa BUMDes

2. Tersedianya dokumen rencana bisnis BUMDes

1. $80 \%$ mampu menyusun kelayakan bisnis BUMDes

2. Tersedianya dokumen kelayakan bisnis BUMDes

1. $80 \%$ Pengurus pengelolaan keuangan BUMDes

2. Tersedianya dokumen administrasi keuangan BUMDes

1. $80 \%$ Pengurus dapat melakukan administrasi BUMDes

2. $80 \%$ Pengurus dapat menyusun laporan keuangan BUMDes
1. $90 \%$ pengurus memahami jenis-jenis usaha yang dapat menjadi peluang usaha BUMDes

2. Pengurus telah mampu menginventarisasi beberapa potensi usaha BUMDes antara lain bidang jasa seperti layanan fotocopy, ATK dan penyewaan kendaaran untuk mengangkut hasil pertanian, dll. Selain sektor jasa, sektor perdagangan juga cukup potensial untuk dikembangkan, seperti pengadaan kebutuhan pokok baik masyarakat dan menjadi supllier bagi para pedagang ,mikro kecil yang ada di desa.

1. $90 \%$ pengurus memahami pentingnya rencana dan kelayakan bisnis BUMDes

2. Pengurus telah mampu menyusun dan memiliki dokumen rencana bisnis BUMDes

. $20 \%$ pengurus memiliki kemampuan menyusun kelayakan bisnis.

2. Pengurus belum mampu menyusun kelayakan bisnis BUMDes

3. Dokumen kelayakan bisnis belum dapat disusun oleh BUMDes

1. $80 \%$ pengurus memahami pengelolaan keuangan BUMDes

2. $80 \%$ pengurus mampu melaksanakan administrasi keuangan BUMDes

3. Dokumen administasi keuangan BUMDes telah tersedia

1. $80 \%$ pengurus memahami administrasi BUMDes

2. $30 \%$ pengurus mampu menyusun laporan keuangan BUMDes

3. Dokumen laporan keuangan BUMDes belum tersedia 


\section{Kesimpulan}

Berdasarkan pelaksanaan dan hasil kegiatan serta rencana tahapan selanjutnya, dapat disimpulkan bahwa BUMDes Mapan Desa Panjalin Kidul Kecamatan Sumberjaya Kabupaten Majalengka, perlu menyusun AD/ART sebagai dasar dalam operasional BUMDes. Selain itu, BUMDes juga memerlukan pengurus yang mampu menyusun rencana dan pengembangan usaha, melaksanakan administrasi dan pengelolaan keuangan serta melengkapi dokumen - dokumen administrasif seperti buku keuangan, buku harian, dan lain-lain.

Berdasarkan kesimpulan diatas, beberapa saran yang dapat dikemukakan antara lain sebagai berikut :

1. Bagi BUMDes, diperlukan penambahan personil pengurus sehingga rasio pengurus dengan fungsi BUMDes dapat diimbangi, dan BUMDes dapat berjalan dengan optimal.

2. Bagi Universitas Majalengka, pendampingan BUMDes MAPAN harus dapat ditindaklanjuti sebagaimana yang disusun dalam rencana tahapan selanjutnya. Upaya ini dapat dilakuan dengan membentuk tim kerja di Fakultas Ekonomi dan Bisnis untuk melaksanakan kegiatan Pengabdian Kepada Masyarakat dengan melibatkan dosen dan mahasiswa.

\section{Daftar Pustaka}

Departemen Pendidikan Nasional Pusat Kajian Dinamika Sistem Pembangunan (PKDSP). (2007). Buku Panduan Pendirian dan Pengelolaan Badan Usaha Milik Desa (BUMDes). Jakarta: Fakultas Ekonomi Universitas Brawijaya.

Ridlwan, Z. (2014). Urgensi Badan Usaha Milik Desa (Bumdes) Dalam Pembangun Perekonomian Desa. Fiat Justisia. Vol 8, No 3, 424-440.

Sofyan, A. (2015). Langkah Persiapan Pendirian Badan Usaha Milik Desa. Diakses 12 Desember 2019 dari http://www.upacaya.com/langkah-persiapan-pendirian-badanusaha-milik-desa/

Universitas Majalengka, 2019. Keputusan Rektor Universitas Majalengka Nomor : 137/KEP/UNMA/IX/2019 Tentang Pengesahan Panduan Hibah Penelitian dan Pengabddian Kepada Masyarakat Universitas Majalengka. 